\title{
Appreciation: Dr William S Rapson (1912 - 1999) A Very Versatile Scientist
}

When his friends were informed that Dr William Sage Rapson had died we could hardly believe it. Many of us had been in frequent contact with him over many years in connection with his great variety of projects. At the time of his death he was still suggesting new directions for work, and writing and reviewing articles. We all appreciated Dr Rapson's acumen, broad perspective and farsightedness, based on a life's experience in leading institutions in Government, Universities and Industry in both basic research and applied R\&D. Dr Rapson's knowledge was very broadly based and included all the principal branches of chemistry and metallurgy, water and mineral resources, and geology, as well as agriculture and food science.

\section{The Young Scientist}

Like his famous countryman, Ernest Rutherford, who changed the course of physics, Bill was a New Zealander. He was born on August 4 1912, and his parents were farmers who lived near Kaihu, a small village in North Auckland and had seven children. Despite his lifelong addiction to farming and animals, Bill right from his early days showed signs of academic excellence. He attended Mt Albert Grammar School where he began as Rawlings Scholar and finished as Senior National Scholar. At Auckland University College recognition continued: Junior University Scholar, Senior University Scholar, Duffus Lubecki Scholar and finally Sir George Grey Scholar - one cannot but admire the teachers who recognized the intellectual abilities of this youngster! At the tender age of 20 he got his masters degree, and from then on things happened very fast, as befits Bill Rapson's style. In 1933 he became lecturer in chemistry at the University College. The following year he decided to follow Ernest Rutherford's example and went to England, but rather than add to the established New Zealand strength in Cambridge, he went to study organic chemistry in Oxford with Professor (later Sir) Robert Robinson. He chose a topic for his research which today is still very prominent, ie steroids, and developed the Rapson-Robinson synthesis whilst completing his thesis in 1935 at the age of 23, during the period of worldwide economic crisis.

On the strength of his achievements in Oxford, he was then appointed lecturer in organic chemistry at the University of Capetown (1935 - 41). Bill's lectures encompassed his encyclopaedic knowledge of organic chemistry; and no one who attended them can ever forget his excruciating technique of conducting classroom quizzes, his eyes sparkling with excitement and enthusiasm behind his spectacles - an enthusiasm that was not always shared by the hapless members of his class as they watched the barrage of questions approaching them! I can but add that this was still his way in industrial-scientific meetings and discussions in later years, and I enjoyed his comments immensely when meetings became boring. One has to comment in German (which Bill enjoyed and mastered fluently) Wilhelm Busch, Plusch und Plum - slightly varied: "Das war William's Manier daß sie gut das sehen wir".

In 1937 at the University of Capetown, Bill met and married a new immigrant young English teacher, Joyce Abey. Joyce had an MA in English, specializing in Old English, from Oxford University, but had unfortunately already sustained a motor bicycle accident which left her permanently disabled, but it turned out that she and Bill had made a mutual choice which was at least as impressive as both of their later careers. Even in her sixties Joyce was a warm, bright, most charming, witty lady, full of 'l'esprit'. Joyce died in 1996, and Bill's date of death coincided with what would have been their sixty second wedding anniversary! He had devotedly looked after Joyce, in spite of the fact that her physical disabilities became an increasing burden for them both.

In 1946 Bill became Professor designate of Chemistry after having been a Senior Lecturer. He not only made himself famous for his lectures and classroom experiments, but also for his research. I 


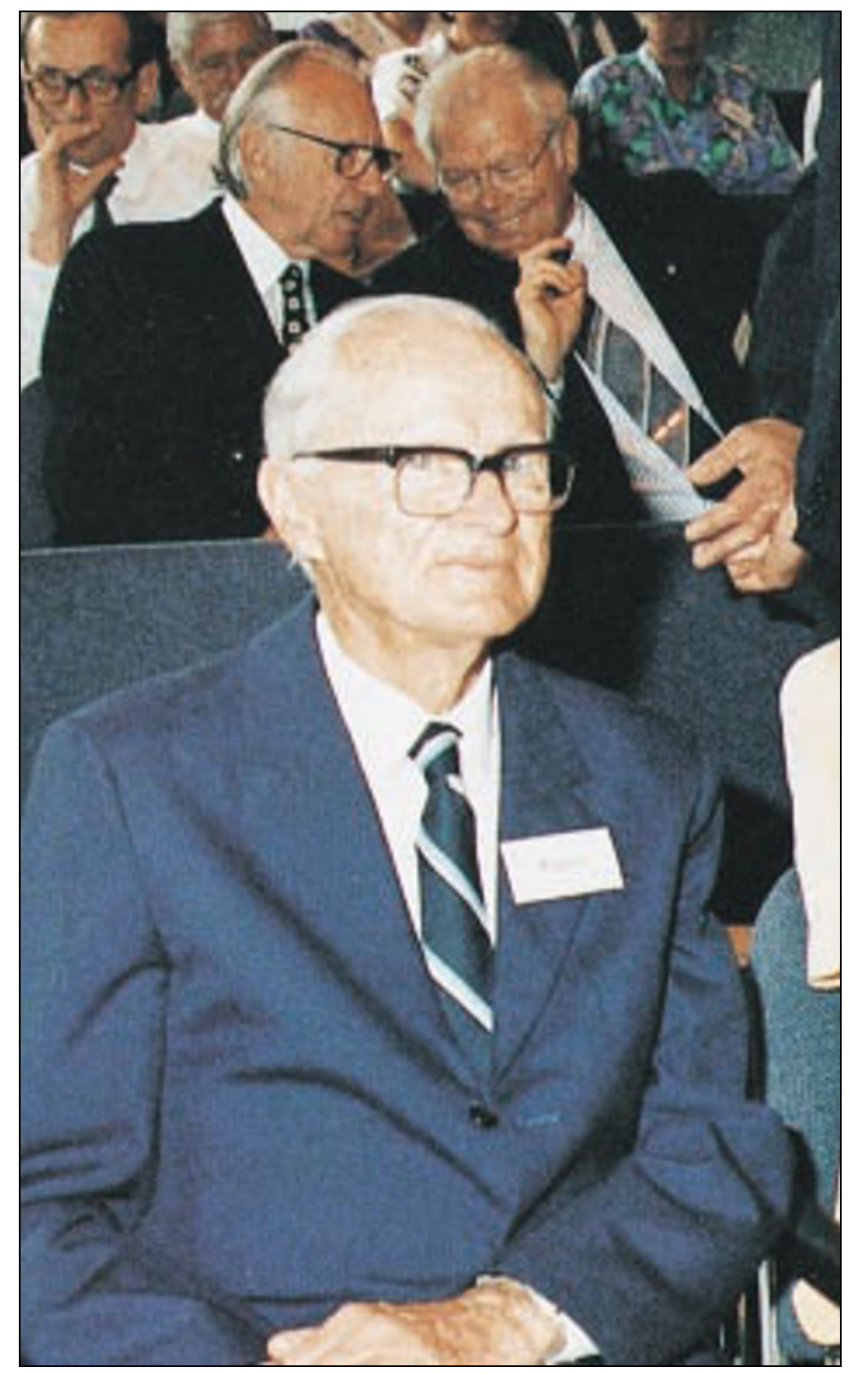

Dr Bill Rapson at the 70th Anniversary celebration of FEM, Schwabisch Gmund, Germany, 1992.

learned that he based his teaching of organic chemistry upon mechanistic electronic theories and also excelled in applied work on natural products, agriculture and food chemistry. For example, it was he who did pioneering work on the fruit and fish resources of the Western Cape area, and the work on fish eventually became the foundation of South Africa's formidable fish oil industry. During wartime he focused his attention on research into the liquefaction of coal and collaborated with the physicists of the University of Cape Town on the development of X-ray diffraction.

\section{The Science Manager}

Thus, the fame of the young chemist spread. About the same time that he became Professor he was asked to join the National Chemical Research Laboratory of the Council for Scientific and Industrial Research (CSIR) in Pretoria as its first Director. In 1958 he was promoted to Vice-President of CSIR. During this time he was responsible for research of national importance to South Africa, switching, I am pleased to say, to inorganic chemistry topics, eg water and mineral resources, and deacidification and desalination methods for waste dumps and rivers. He once told me how he identified a grass, which would grow on the acidic sand hills of the tailings around Johannesburg at $\mathrm{pH} 2-3$, in order to keep the pyritic quartzite sands from being blown into rivers and polluting them.

In 1958 Bill changed again. In the words of W Busch (Tobias Knopp) this would read: "Dieses ist erkedigt nun, William kann was andres tun!" An important resource in South Africa was gold but its exploitation needed to be better organized. When it was decided to do something about research for the gold industry, Bill, whose reputation in the mining industry was already well established from his work on water resources, was appointed Research Advisor to the Transvaal and Orange Free State Chamber of Mines, later the Chamber of Mines of South Africa, which turned out to be a very demanding practical role requiring the provision of vital technical advice for General Managers and Presidents of Company Boards.

When Dr Rapson accepted this position he soon recognized that the problems of the gold mining industry were such that only a well structured and long range research programme could address them, $i e$ in the course of more than 7,000 years objects made from gold, including decorative jewellery, coins and electronic parts, were produced mainly on the basis of empirical knowledge, by trial and error. Knowhow was tightly guarded by everyone from street goldsmiths in Bombay to researchers at ATT Bell Telephone Laboratories in the USA. Bill's task involved not only mineral resources and metal winning or purification of gold, but also the promotion and commercial sales of the metal. His first goal, therefore was to set up the necessary research infrastructure to counter the empirical state of affairs and to appoint people with the right qualities to carry out the research. He was very successful in doing this and within a few years the quality of the Chamber's research organization was acknowledged worldwide. When in 1974 he handed over the research organization to Dr Miklos Salamon, he did this with the simple words: "Miklos, it's all yours. If you need help you can call on me" - it was one of the characteristics of Bill Rapson that he would not look back, and he always looked for new challenges. 


\section{The Work on Gold}

The empirical state of affairs was certainly the situation in 1972 when Bill first came to FEM. He came with Theo Groenewald to sort out the situation of gold manufacturing worldwide. This resulted immediately in a research programme, funded by the gold mines, to improve production and eliminate waste. Results of this work were to be spread as far and as fast as they could - for the benefit of both producers and users! Two journals disseminated information on gold. One of these was Gold Bulletin, which had existed earlier under the able editorship of Dr Leslie B Hunt, and sponsored by Johnson Matthey. This was now soon taken over by the International Gold Corporation later to become the World Gold Council - which also publishes Gold Technology where the focus is on practical topics of jewellery production.

In 1978 Bill wrote the book 'Gold Usage' in collaboration with Dr Theo Groenewald, the first gold textbook to be published since E Raub's 'Die Edelmetalle und Ihre Legierungen' (1940); but the latter had only a few chapters on gold and its alloys. Bill asked my father - at that time already more than 70 years of age - to write the Foreword and I was allowed to assist with the English! 'Gold Usage' became the principal reference book on the Science and Technology of gold and its alloys, containing a wealth of useful information. It was so well accepted that Bill was asked to write a second revised version, including the wider aspects of gold science and technology now developing. Bill's, accurate, precise, careful and correct manuscript, was finished long before he died, and delivered 'on time' - we eagerly await its publication which is long overdue! Since he held 'Die Edelmetalle und Ihre Legierungen' in such a high esteem, Bill set out to translate it from German into English, proving his superb command of German. Again, Bill kept to the deadline, but the publisher is late so it will be available post mortem.

The many articles Bill wrote on gold for Gold Bulletin together with the large number of papers written by others which he reviewed or edited, all show, how he - an organic chemist of renown - grasped the tenets of metal science and metal winning. It was he in the area of metallic gold, its alloys and usage, who promoted so many research programmes and obtained funding for them. Bill still actively participated in jewellery fairs and technical meetings on gold at Vicenza, Santa Fe, Hanau and Schwäbisch Gmünd whilst more than 80 years of age, and made his own contributions. He consulted on developing markets, promoted development of new alloys, introduced new production processes and started investigations on casting and studies on electroplating as well as on properties of the deposits for electronics. In Schwäbisch Gmünd Bill became a highly honoured and esteemed speaker, as well as a very welcome personal guest in our home on many occasions.

His work with the WGC lasted right up until the time of his death, and he, for example even contributed a Guest Editorial for Gold Bulletin (1999, 32, 74) only two weeks before his death. Until his last hours Bill was actively engaged in thinking about everything connected with his many fields of interest. Curious and courageous as he always had been, Bill would dearly have loved to go underground in the Middle Ages mines, Alte Elisabeth and Reiche Zeche, at Freiberg in Saxonia, after it became possible in 1989, we planned to do so, but somehow never managed to achieve this. He was similarly fascinated by the annual Babara-Fest of the Bergakademie Freiberg, honouring the patron saint of miners, smelters and metallurgists, as well as artillery men. Bill was not so much the 'Pope' of Modern Gold, as he was named by a South African Manager, but he was definitely its father. We must continue to build in his legacy!

Bill received countless honours and gold medals, the exact number of which neither he nor Joyce did ever remember accurately. I am wondering if he ever was offered a bronze or silver medal - or if he ever accepted a platinum or palladium medal, metals he for a while called 'The White Danger!'? Bill, at one time or another in his life, was made either Fellow or President of nearly every Professional Society in the field of Applied Chemistry in South Africa. Despite his four doctorates, I never saw him using even one Joyce was the same. Surrounding his honours there were often awe-inspiring rumours - generally proving to be true.

\section{The Person}

All his technical achievements were superseded, however, by Dr Rapson's personal attitudes and his character. He placed duties more highly than rights in his own life and asked the same of his collaborators. $\mathrm{He}$ automatically demanded and received the highest respect, in spite of the fact that he asked for a lot. But it was never more than he himself was ready to give. He once explained to me: "Chris, mining is deadly dangerous - therefore it must be handled responsibly, just as in a military operation". This respect resulted in a certain distance between him and others and only after opening up, was Bill's 'Golden Heart' really evident. He 
must certainly have been an ideal grandfather to his grandchildren in Zimbabwe and Canada.

It was an unforgettable experience when on one visit to South Africa I was invited to spend two weeks touring mines and installations in South Africa with Joyce and Bill, we were received like kings - or like Dr W S Rapson! Before we went underground (officially guests who are more than 60 years old are forbidden underground, but this regulation was waived for Dr Rapson) the two of us were the only guests received by the General Manager in his 'Office' which looked to me more like a 'Hall' due to its sheer size. Three PhD chief geologists from the company explained the situation at the Reef. When we toured underground the leading expert on manganese in South Africa, nicknamed 'Mr Manganese'- told me "In no part of the world will you be badly treated if you are with Bill Rapson". Even Bill was impressed, asking me :"Chris, do you know how much our visit costs the mine?", since production had been stopped for our visit.

One of Bill's characteristics was his 'penny consciousness'. On his business trips, hotels with chromium plated furniture and every comfort were a horror to him. A simple clean country-style hotel, representative of the country and its people, was more to his liking. I wonder how he treated his collaborator's travel expense accounts?!" His frugality was impressive: Every letter I received came the cheapest way, as an 'Aerogramme', handwritten in small but very legible fine characters. On the other hand, if Bill received an honorarium for his presentations, he always gave it to those who needed it more than he did and several guests from our Institute do not know that their travel fees really were paid by Dr. Rapson, directly or indirectly.

Bill could be a great charmer if the person attracting his attention was to his liking: In Schwäbisch Gmünd at an anniversary of the Institute, Bill as honoured guest was seated near another featured speaker, a lady from France. After her presentation in German, with a charming French accent, Bill with a sparkle in his eyes and a puckish smile told me: "Chris, you know what I did ? I kissed her four times, twice on each cheek!"

Dr Joyce Rapson was a most appropriate counterpart and life partner for Bill. Few know that Bill for many years was encouraging her to publish her thesis. When this finally happened, Joyce was already more than 60 years of age. Bill himself typed the thesis on an old typewriter. He later jokingly asked me "Should I have added under 'Acknowledgements': I want to thank my husband, Dr W S Rapson, retired, for his two finger typing of my manuscript". One of Dr Joyce Rapson's comments - which were always very pertinent 'hits' - was very revealing. On our way back to Johannesburg from the Krüger Park we had to stop at nearly every fence for Bill to admire the sheep and cattle herds. Joyce, who was an English city lady who did not have infinite patience with cows, muttered: "Way down in his heart he is still a cow-pock" (or did she say cowboy?) - then she wondered if I would understand it properly and added - "but a lovable one".

Joyce and Bill, both of you will remain part of the lives and memories of people who are proud to have been called your friends. What you did for the people of your country and for the Community of Technology is best described by one of your predecessors, Roger von Helmarshausen or Theophilus the Monk, who in the 12th century finished the 'Prologue' to his famous book "On divers ars", the Middle Age's 'Gold Usage': "I have neither stolen anything precious or rare nor silently received anything for myself alone, but rather that I have given aid to many men in their need and have had concern for their advancement to the increase of the honour and glory of his name." On June 25 1999 modern Gold lost its father, and we are missing a dear friend.

\section{ACKNOWLEDGEMENTS}

I thank the Rapson's daughters Dr D Rapson-Kamal, Kingston, Canada and J Dorward, Harare, Zimbabwe; and the University of Capetown, the Chamber of Mines of South Africa, Marshalltown, Drs C W Corti, WGC, London, $T$ Groenewald, Johannesburg and Prof Dr H Wagner, Montanuniversität Loeben, Austria for providing information on various aspects of $\mathrm{Dr}$ Rapson's life. To Dr Rapson-Kamal, Mrs J Dorward and Dr Corti and Thompson, I am especially grateful for assistance with the manuscript.

Prof Dr Christoph J Raub Schwäbisch Gmünd Germany

\author{
ABOUT THE AUTHOR \\ Professor Raub was Director of Forschungsinstitut für Edelmetalle und \\ Metallchemie (FEM) in Schwäbisch Gmünd from 1970 to 1995. He \\ is author or co-author of nearly 500 publications and throughout his \\ working life has always been concerned with research, development \\ and applications of gold and its alloys and compounds. Since \\ retirement he has concentrated on historical and archaeological aspects.
}

